\title{
Performance of Selected Herbaceous Annual Ornamentals Grown at Decreasing Levels of Irrigation
}

\author{
D. Yvette Henson, Steven E. Newman, and David E. Hartley ${ }^{1,2}$ \\ Department of Horticulture and Landscape Architecture, Colorado State \\ University, Fort Collins, CO 80523-1173
}

Additional index words. bedding plants, drought, evapotranspiration

\begin{abstract}
This study was conducted to evaluate the growth, visual quality, and stress response of 17 species of bedding plants and Kentucky bluegrass (Poa pratensis L.) grown outdoors for 10 weeks during the summer of 2003 at three locations in Colorado. Plants were irrigated at $100 \%$ of the reference evapotranspiration $\left(\mathbf{E T}_{0}\right)$ (amount required to maintain Kentucky bluegrass in an optimum condition) for 2 weeks followed by 8 weeks at five irrigation levels: $0 \%, 25 \%, 50 \%, 75 \%$, and $100 \%$ ET $_{0}$. Begonia carrieri Hort. 'Vodka', Lobelia erinus L. 'Cobalt Blue', and Viola $\times$ wittrockiana Gams. 'Crown Gold' grew well with a minimum of $50 \%$ or more $\mathbf{E T}_{0}$ based on Kentucky bluegrass. Impatiens walleriana Hook. fil. 'Tempo White' grew well only with $100 \%$ ET $_{0}$. Antirrhinum majus L. 'Sonnet Yellow', Dianthus L. 'First Love', Lobularia maritima (L.) Desv. 'Carpet White', and Pelargonium $\times$ hortorum L.H. Bailey performed well with $25 \%$ to $50 \% \mathbf{E T}_{0}$. The species Catharanthus roseus (L.) G. Don 'Peppermint Cooler', Rudbeckia hirta L. 'Indian Summer', Senecio cineraria D.C. 'Silver Dust', Tagetes erecta L. 'Inca Yellow' and T. patula L. 'Bonanza Gold', Zinnia angustifolia Kunth., and Salvia farinacea Benth. 'Rhea Blue', which are adapted to midsummer heat and low water, performed well with $\mathbf{0} \%$ to $25 \% \mathrm{ET}_{\mathbf{0}}$. Species considered to be heat or drought tolerant-Petunia $\times$ hybrida hort. ex. E. Vilm. 'Merlin White' and Glandularia J.F. Gmel. 'Imagination'-required little or no irrigation. The bedding plant species evaluated in this study that required $\mathbf{2 5 \%}$ or less $\mathbf{E T}_{\mathbf{0}}$ are well adapted for low-water landscape installations.
\end{abstract}

Water conservation is becoming an increasingly pertinent issue in Colorado and the intermountain Rocky Mountain west. Colorado has a semiarid to arid climate with recurrent drought periods (Doesken, 2004; Tweit, 2004) and limited water resources (Oad and DiSpigno, 1997). Add to this population growth (Ellefson and Winger, 2004; Oad et al., 1997; Tweit, 2004), which in turn increases the strain on water resources. There is a great deal of information reported in the literature quantifying the water requirements of food crops and turfgrass; however, data quantifying the irrigation requirements of ornamental plants required to maintain healthy growth and acceptable quality is minimal at present.

Past reports have classified ornamental plants as low, medium, and high water users based on anecdotal evidence. A California study with groundcovers reported that $50 \%$ of evapotranspiration $\left(\mathrm{ET}_{0}\right)$ (level of irrigation required to maintain Kentucky bluegrass in an optimum condition) was the minimum

Received for publication 14 Feb. 2006. Accepted for publication 24 Mar. 2006. This work was funded by Welby Gardens, Inc., the Colorado State University Specialty Crops Program, the Colorado Floriculture Foundation, and the Colorado Agr. Expt. Sta.

${ }^{1}$ Former Graduate Research Assistant, Extension Specialist, and Associate Professor.

${ }^{2}$ To whom reprints requests should be addressed; e-mail steven.newman@colostate.edu. amount of irrigation to maintain acceptable plant quality (Pittenger et al., 1990). Yet, there was considerable variability among species. A later study indicated that for Vinca L., Gazania Gaertn., and Potentilla L., there was no improvement in aesthetic appearance when irrigated at more than $30 \% \mathrm{ET}_{0}$. Baccharis L., Drosanthemum Schwant., and Hedera L. showed no improvement in appearance when grown above $20 \% \mathrm{ET}_{0}$ (Pittenger et al., 1992). Other California investigations concluded that irrigation less than or equal to $14 \%$ of $\mathrm{ET}_{0}$ can be applied to established groundcovers and shrubs with no adverse affects on health and appearance (Sachs, 1991).

Previous work reported from Colorado, where 45 herbaceous perennial plants native to the western United States were subjected to irrigation and no irrigation, demonstrated no differences among irrigation treatments (Cox and Klett, 1984). Staats and Klett (1995) reported that for Kentucky bluegrass (Poa pratensis L. 'Challenger'), 50\% bluegrass $\mathrm{ET}_{0}$ was the optimum irrigation level, whereas Cerastium tomentosum L. required irrigation between $50 \%$ and $75 \%$ bluegrass $\mathrm{ET}_{0}$ in one season and $25 \% \mathrm{ET}_{0}$ during the following season. Potentilla tabernaemontani Asch. required irrigation at $75 \% \mathrm{ET}_{0}$ and Sedum acre L. did well at $25 \% \mathrm{ET}_{0}$ (Staats and Klett, 1995). Taken together, these findings demonstrate substantial variation in water requirements for ornamental plants grown in Colorado.
This study was conducted to determine water requirements and quantify the growth, visual quality, and health of 17 popular species of bedding plants grown outdoors under Colorado conditions compared with Kentucky bluegrass (Poa pratensis L). The objectives of this research were to provide information on minimum irrigation requirements for annual herbaceous ornamental plants to be used by landscape professionals.

\section{Materials and Methods}

The bedding plant species for this study were chosen based on their status as topselling bedding plants in Colorado according to local greenhouse professionals (D. Gerace, Welby Gardens, Inc., Denver, Colo., pers. comm.). Poa pratensis L. (Kentucky bluegrass) was included in the study for comparison because the calculated reference evapotranspiration $\left(\mathrm{ET}_{0}\right)$ value was based on this species. The 17 herbaceous annual ornamental species tested included Antirrhinum majus L. 'Sonnet Yellow' (snapdragons); Begonia carrieri Hort. 'Vodka' [syn. Begonia semperflorens 'Vodka' (red-leaved wax begonias)]; Catharanthus roseus (L.) G. Don 'Peppermint Cooler' (Madagascar periwinkle or vinca); Dianthus L. 'First Love'; Impatiens walleriana Hook. fil. 'Tempo White' (impatiens); Lobelia erinus L. 'Cobalt Blue'; Lobularia maritima (L.) Desv. 'Carpet White' (sweet alyssum); zonal geraniums Pelargonium $\times$ hortorum L.H. Bailey 'Americana Red' (Fort Collins), Pelargonium $\times$ hortorum L.H. Bailey 'Kim Red' (Denver), and Pelargonium $\times$ hortorum L.H. Bailey 'Americana Pink' (Grand Junction); Petunia $\times$ hybrida hort. ex. E. Vilm. 'Merlin White'; Rudbeckia hirta L. 'Indian Summer' (black-eyed Susan); Salvia farinacea Benth. 'Rhea Blue' (mealycup sage or salvia); Senecio cineraria D.C. 'Silver Dust' (dusty miller); Tagetes erecta L. 'Inca Yellow' (African marigold); Tagetes patula L. 'Bonanza Gold' (French marigold); Glandularia 'Imagination' [Glandularia J.F. Gmel. 'Imagination' (syn. Verbena 'Imagination') is either a species of Glandularia tenuisecta (Briq.) Small (syn. V. tenuisecta Briq.), moss verbena or a hybrid between Glandularia tenuisecta and Glandularia tenera (Spreng.) Cabera (syn. V. tenera Spreng.), Latin American mock vervain. For clarification, this plant will be referred to as Glandularia in this manuscript.]; Viola $\times$ wittrockiana Gams. 'Crown Gold' (pansies); and narrow-leaf zinnias Zinnia angustifolia Kunth. 'Crystal White' (Fort Collins and Denver) and Zinnia angustifolia 'Crystal Orange' (Grand Junction). Cultivar differences among locations for Pelargonium and Zinnia were the result of issues with availability. Similar trends were observed for each of the cultivars among locations and the data were consequently pooled.

All herbaceous ornamental plants used in the field trials were commercially grown from $F_{1}$ hybrid seed or cuttings (Welby Gardens, Inc., Denver, Colo.) using a traditional sphagnum peat moss and vermiculite 
substrate, and were transplanted to plastic 804 trays, 606 trays, or $10-\mathrm{cm}$ pots (zonal geraniums). Initially plants were greenhouse grown and subsequently hardened by limiting water before transplanting into the trial beds.

The three locations used included a campus site, an urban site, and a site in western Colorado. The urban location was in Denver, Colo., at elevation $1553 \mathrm{~m}$; latitude, $39.83^{\circ}$; longitude, $-104.95^{\circ}$. The campus location was in Fort Collins, Colo., at elevation 1522 $\mathrm{m}$; latitude, $40.57^{\circ}$; longitude, $-105.09^{\circ}$. The western Colorado location was in Grand Junction, Colo. at elevation $1416 \mathrm{~m}$; latitude, $39.04^{\circ}$; longitude, $-108.54^{\circ}$.

Each location required some soil amendment. The Denver location was a clay soil and was amended with $0.018 \mathrm{~m}^{3}$ of sphagnum peat moss $\cdot \mathrm{m}^{-2}$. The Fort Collins location was a loam soil, which had been amended during previous years with various organic amendments. Grand Junction soils are typically very saline; therefore, the Grand Junction location was a raised bed and was filled with a sandy loam native topsoil. The raised bed was $1 \mathrm{~m}$ high, with 10 -cm-thick cement walls and a bottom layer of gravel covered by landscape fabric. One application of a full-season, complete nutrient $(7 \% \mathrm{~N}-0.874 \% \mathrm{P}-4.98 \%$ $\mathrm{K})$, and combined soluble and slow-release fertilizer (HARDY START; Welby Gardens) was applied at a rate of $122 \mathrm{~g} \cdot \mathrm{m}^{-2}$ and lightly tilled into each plot before planting at each location.

Each bedding plant species was planted in a $1-\mathrm{m}^{2}$ square with nine plants spaced $25.4 \mathrm{~cm}$ on center. Kentucky bluegrass sod was planted in $61 \times 76-\mathrm{cm}$ blocks (Denver and Fort Collins) and $76 \times 76-\mathrm{cm}$ blocks (Grand Junction) by placing it on top of the drip tapes and building soil up around the edges. Planting was completed 28 May 2003 in Denver, 29 May 2003 in Fort Collins, and 17 July 2003 in Grand Junction. The Grand Junction location was planted late to accommodate for the travel distance and to schedule the peak bloom, because late summer and early fall temperatures would be more suitable for bedding plant performance.

The beds were mulched with $1.25 \mathrm{~cm}$ cedar bark in Denver and Fort Collins and $1.25 \mathrm{~cm}$ shredded wood from pallets in Grand Junction. All weeding was done by hand at all locations. Insecticides were used only if severe infestations of insects occurred. No dead heading of blooms was done except on zonal geraniums. Differences between mulch colors used at the Denver and Fort Collins locations compared with the Grand Junction location were negligible.

The irrigation treatments included five levels, determined as $0 \%, 25 \%, 50 \%, 75 \%$ and $100 \%$ of the reference evapotranspiration $\left(\mathrm{ET}_{0}\right)$ required for optimum Kentucky bluegrass growth. Daily weather data (temperature, solar radiation, wind speed, and relative humidity) were collected from local weather stations, which were used to calculate locationspecific $\mathrm{ET}_{0}$ using the Penman-Montieth equation (Qian et al., 1996).
Each irrigation zone (irrigation level based on percent $\mathrm{ET}_{0}$ ) was operated by a separate solenoid valve. Flow meters were installed to measure the actual water volume of irrigation water applied to each zone. Water flow was then calibrated to ensure accuracy among treatments. Two lines of drip tape were installed $25.4 \mathrm{~cm}$ apart along the center of all experimental units from end to end of each whole plot. The drip tape was $1.6 \mathrm{~cm}, 8 \mathrm{~mm}$ polyethylene (Chapin Watermatics, Inc., Watertown, N.Y.) with emitters every $20.3 \mathrm{~cm}$ and had an output of 203 $\mathrm{mL} \cdot \mathrm{min}^{-1} \cdot \mathrm{m}^{-2}$.

Irrigation was automatically applied to whole plots using a WeatherTRACK ${ }^{\circledR}$ ET Controller (HydroPoint Data Systems, Petaluma, Calif.). Daily weather data for the Denver location was collected from an onsite weather station from which $\mathrm{ET}_{0}$ was determined. Daily weather data for the Fort Collins location was collected from a nearby Northern Colorado Water Conservancy weather station located in central Fort Collins from which $\mathrm{ET}_{0}$ was determined. Daily weather data for the Grand Junction location used a network of local weather stations to obtain an "ET everywhere" value. HydroPoint Data Systems distributed these daily $\mathrm{ET}_{0}$ values to each ET Controller via cellular technology. The ET controller automatically adjusted the irrigation output for each irrigation zone $\left(\% \mathrm{ET}_{0}\right)$ accordingly. Each ET controller was programmed for each location's soil type, type of landscape plant material (flowers), depth of irrigation, slope and exposure, and time of day to begin irrigation. Temperature data from each location are included in Figs. 1 through 3.

Each zone was entered into the controller by subtracting out $75 \%$ for the $25 \%$ zone, $50 \%$ for the $50 \%$ zone, and $25 \%$ for the $75 \%$ zone. The $0 \% \mathrm{ET}_{0}$ zone received only natural precipitation (no irrigation). The $100 \%$ zone was $100 \%$ of the reference ET $\left(\mathrm{ET}_{0}\right)$ for Kentucky bluegrass (i.e., the ET required to grow Kentucky bluegrass to optimum - up to $3.28 \mathrm{~cm}$ water $\cdot \mathrm{m}^{-2} \cdot \mathrm{week}^{-1}$ ). Irrigation applied to each zone as well as natural rainfall is included in Table 1. A rain sensor shutoff valve (Hunter Mini-Click, Cary, N.C.) was connected to the ET controller to initiate an automatic rain pause when $0.32 \mathrm{~cm}$ rain was detected. The daily data sent to the ET controller would initiate a rain pause for a calculated number of days after a rain event as well. All plots were irrigated to $100 \% \mathrm{ET}_{0}$ for 2 weeks after planting and were then subjected to the irrigation treatment levels for the following 8 weeks.

Percent cover, plant biomass, leaf temperature, and visual evaluations were collected to contrast the growth and health of each species at the different levels of irrigation at all three locations.

Percent cover using the point intercept method (Daubenmire, 1959) was measured every other week for 8 weeks at each location using a grid constructed from a $1-\mathrm{m}^{2}$ frame constructed from polyvinyl chlorine pipe. An acceptable final percent cover was calculated

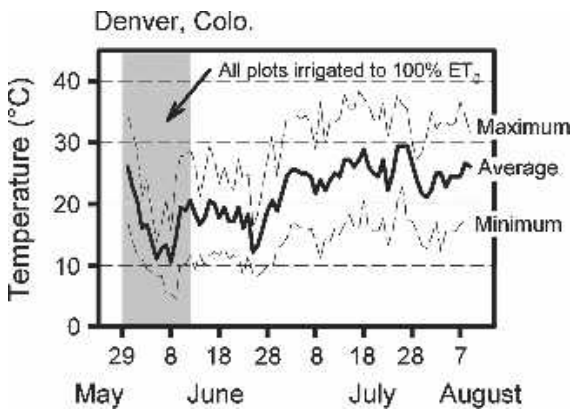

Fig. 1. Average daily temperature with maximum and minimum temperatures for Denver, Colo., collected during the first 2-week establishment period followed by the 8 -week study period. The temperature data were collected from the National Oceanic \& Atmospheric Administration weather station located at Denver International Airport, Commerce City, Colo.

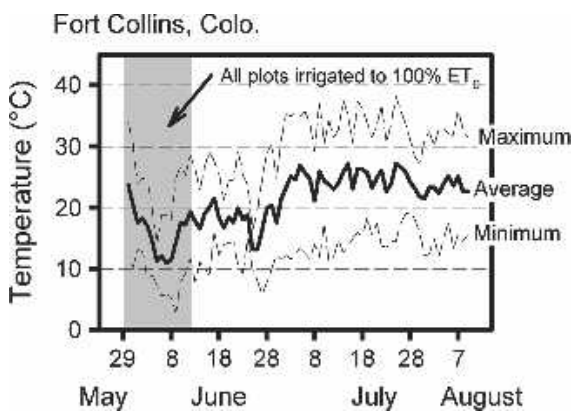

Fig. 2. Average daily temperature with maximum and minimum temperatures for Fort Collins, Colo., collected during the first 2-week establishment period followed by the 8 -week study period. The temperature data were collected from the Northern Colorado Water Conservancy District weather station located in central Fort Collins, Colo.

Grand Junction, Colo.

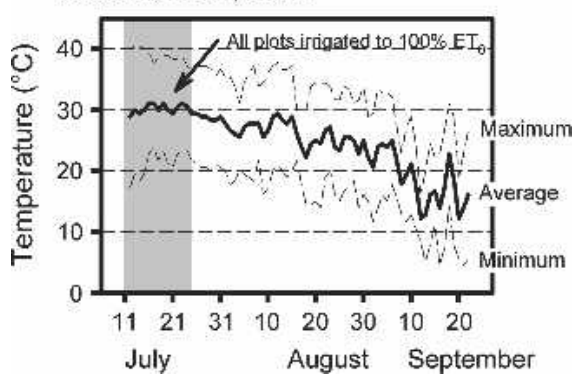

Fig. 3. Average daily temperature with maximum and minimum temperatures for Grand Junction, Colo., collected during the first 2-week establishment period followed by the 8 -week study period. The temperature data were collected from the National Oceanic \& Atmospheric Administration weather station located at Grand Junction Walker Field, Grand Junction, Colo.

for each species by taking its highest cover, dividing it by 93 (the highest average percent cover achieved by a plant species in the study), and then multiplying that by 75 . This formula was used based on $75 \%$ being 
Table 1. Rainfall and drip irrigation applied to each subplot as determined by evapotranspiration $\left(\mathrm{ET}_{0}\right)$ at each location for the 10-week duration of the study.

\begin{tabular}{|c|c|c|c|c|c|c|}
\hline & & \multicolumn{5}{|c|}{ Irrigation level $\left(\% \mathrm{ET}_{0}\right)$} \\
\hline & & 100 & 75 & 50 & 25 & 0 \\
\hline$\overline{\text { Denver }}^{y}$ & Applied irrigation & 24.9 & 18.6 & 11.6 & 6.25 & 0 \\
\hline Fort Collins ${ }^{x}$ & Irrigation plus rainfall & 32.9 & 25.2 & 20.4 & 12.1 & 6.21 \\
\hline \multirow[t]{2}{*}{ Grand Junction $^{w}$} & Applied irrigation & 23.3 & 22.0 & 9.55 & 4.57 & 0 \\
\hline & Irrigation plus rainfall & 26.1 & 24.8 & 12.4 & 7.39 & 2.82 \\
\hline
\end{tabular}

${ }^{2}$ Applied irrigation levels were calculated based on the volume of water applied, as determined by an inline recording device, and the area to which that volume was applied via the drip irrigation system.

${ }^{y}$ Rainfall data from the National Oceanic \& Atmospheric Administration weather station located at Denver International Airport, Commerce City, Colo.

${ }^{x}$ Rainfall data from Northern Colorado Water Conservancy District weather station located in central Fort Collins, Colo.

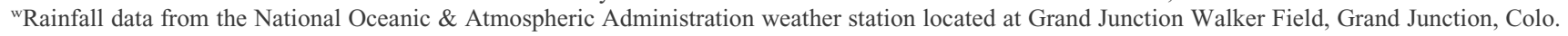

Table 2. Plant quality evaluation of 17 bedding plant species and Kentucky bluegrass grown at five irrigation levels based on evapotranspiration for Kentucky bluegrass $\left(\mathrm{ET}_{0}\right)$ in Denver and Fort Collins, Colo.

\begin{tabular}{|c|c|c|c|c|c|c|c|c|c|c|}
\hline \multirow[b]{3}{*}{ Species } & \multicolumn{5}{|c|}{ Irrigation level $\left(\% \mathrm{ET}_{0}\right)$} & \multirow{2}{*}{\multicolumn{5}{|c|}{ ANOVA }} \\
\hline & 100 & 75 & 50 & 25 & 0 & & & & & \\
\hline & \multicolumn{5}{|c|}{ (Rating) } & Irrigation & Location & $\mathrm{I} \times \mathrm{L}$ & Linear & Quadratic \\
\hline Antirrhinum & 3.33 & 3.16 & 3.15 & 2.65 & 2.23 & 0.0019 & 0.0136 & NS & 0.0003 & 0.0211 \\
\hline Begonia & 3.93 & 3.54 & 2.70 & 1.62 & 0.67 & 0.0004 & NS & NS & 0.0001 & NS \\
\hline Catharanthus & 4.33 & 4.10 & 3.44 & 3.21 & 2.62 & 0.0001 & NS & NS & 0.0001 & NS \\
\hline Dianthus & 4.11 & 3.78 & 3.24 & 2.43 & 1.98 & 0.0025 & 0.0001 & NS & 0.0003 & NS \\
\hline Impatiens & 3.63 & 2.63 & 2.43 & 1.13 & 0.39 & 0.0121 & 0.0183 & 0.0201 & 0.0017 & NS \\
\hline Lobelia & 3.89 & 3.40 & 2.77 & 2.04 & 1.08 & 0.0027 & NS & NS & 0.0004 & NS \\
\hline Lobularia & 3.50 & 3.80 & 3.26 & 1.78 & 1.10 & 0.0057 & 0.0282 & NS & 0.0010 & 0.0380 \\
\hline Pelargonium & 4.04 & 3.41 & 2.97 & 2.36 & 1.60 & 0.0018 & NS & NS & 0.0002 & NS \\
\hline Petunia & 4.64 & 4.63 & 4.21 & 3.91 & 3.41 & 0.0016 & 0.0039 & NS & 0.0002 & 0.0477 \\
\hline Poa & 4.73 & 4.15 & 3.38 & 1.74 & 0.43 & 0.0007 & NS & NS & 0.0001 & 0.0472 \\
\hline Rudbeckia & 4.61 & 4.64 & 4.03 & 3.70 & 2.58 & 0.0002 & NS & NS & 0.0001 & 0.0018 \\
\hline Salvia & 4.57 & 4.14 & 3.85 & 3.36 & 2.51 & 0.0008 & NS & NS & 0.0001 & NS \\
\hline Senecio & 4.60 & 4.30 & 3.70 & 3.49 & 2.88 & 0.0042 & 0.0177 & NS & 0.0006 & NS \\
\hline Tagetes erecta & 4.60 & 4.64 & 3.89 & 3.58 & 2.80 & 0.0001 & NS & NS & 0.0001 & 0.0024 \\
\hline T. patula & 4.45 & 4.26 & 3.65 & 3.07 & 2.43 & 0.0002 & NS & NS & 0.0001 & 0.0307 \\
\hline Glandularia & 3.85 & 3.93 & 3.67 & 3.27 & 3.15 & NS & 0.0018 & 0.0084 & NS & NS \\
\hline Viola & 3.17 & 3.10 & 2.44 & 1.64 & 1.06 & 0.0133 & NS & NS & 0.0021 & NS \\
\hline Zinnia & 4.62 & 4.42 & 4.04 & 3.18 & 2.58 & 0.0047 & 0.0437 & NS & 0.0007 & NS \\
\hline
\end{tabular}

Evaluation was from 0 to 5 , where 0 indicated dead or mostly dead plants; 2 indicated fair to moderate signs of stress, 3 indicated good plant growth with minimal signs of stress; 4 indicated very good plant growth with no signs of stress, insects, or disease; and 5 indicated excellent plant growth with no signs of stress, insects, or disease.

${ }^{\mathrm{N} N}$ Nonsignificant.

acceptable cover (Al-Kaisi and Broner, 2002).

Realizing that with a diverse collection of bedding plant species with differing growth habits, percent cover may not accurately assess plant growth when using only one plant spacing. To accommodate for that issue, the percent change in cover was also determined to compare plant growth among species. The first measurement of percent cover was used as a covariate for the next three subsequent measurements of percent cover to reduce variation among the experimental units. The difference between the final percent cover and the initial percent cover was analyzed as percent change.

Plant biomass was collected at the end of 8 weeks in Denver and Fort Collins only. No plant biomass was collected at Grand Junction. This was completed by cutting the four corner plants in each group at soil level and drying at $70{ }^{\circ} \mathrm{C}$.

Plant temperatures were determined at all three locations with a hand-held IR thermometer (Omegascope, model 05530; Omega Engineering, Stamford, Conn.) (Hatfield, 1990). This was completed two or three times every other week at each location between $11 \mathrm{AM}$ and 1 PM Mountain Standard Time by aiming the IR thermometer at the center of each meter-square group of plants while maintaining a distance of $30 \mathrm{~cm}$. The temperatures were recorded and the canopy temperature was subtracted from the air temperature [canopy temperature - air temperature $(\Delta \mathrm{T})$ ] to obtain a measure of drought stress under decreasing levels of irrigation.

Plant visual evaluation was conducted during the All American Selections Annual Flower Trial Garden evaluations at the Denver and Fort Collins locations only at the beginning of Aug. The Grand Junction location was not evaluated. The evaluators were asked to rate each species on a scale of 0 to 5 , where 0 indicated dead or mostly dead plants; 1 indicated poor or extensive wilting, curling, burning or discoloring, and insect or disease damage to plants; 2 indicated fair to moderate signs of stress, and insect or disease damage; 3 indicated good plant growth with minimal signs of stress, and insect or disease damage; 4 indicated very good plant growth with no signs of stress, insects, or disease; and 5 indicated excellent plant growth with no signs of stress, insects, or disease. Visual plant ratings were averaged for each species within each treatment to determine the lowest irrigation level where each species still maintained acceptable visual quality. An evaluation score of 3 points or more at any level was used to determine the lowest irrigation level where growth and appearance were acceptable.

The experimental design was a split plot replicated at three locations. Each location had $500 \mathrm{~m}^{2}(20 \times 25 \mathrm{~m})$ of planted area. This was divided into whole plot treatments, which included the five levels of irrigation. Within each of these irrigation whole plots were the subplots, which included the 18 species randomly placed. Each subplot treatment contained five $1-\mathrm{m}^{2}$ observations.

Effects for irrigation, location, and replications nested within location were determined by species (for each species separately) with analysis of variance using general linear models (PROC GLM, releases 8 and 9.1; SAS Inst., Carey, N.C.). A mixed model was used when irrigation was a fixed effect, location a random effect, and the five subsamples (replications of experimental units) nested within locations as a random 
effect. The treatment (irrigation) effect was partitioned into linear and quadratic contrasts.

\section{Results and Discussion}

Eight weeks after the imposed irrigation treatment levels, a visual rating of three points indicated good plant growth with minimal signs of drought stress, and insect or disease damage. The plants were fairly uniform and vigorous in growth and flowering. Only Petunia and Glandularia maintained a plant quality of three points or more for the lowest irrigation level: $0 \% \mathrm{ET}_{0}$ (Table 2). Glandularia plant quality was unaffected by irrigation level. Glandularia 'Imagination' is either a species of Glandularia tenuisecta (syn. V. tenuisecta), moss verbena, or a hybrid between Glandularia tenuisecta and Glandularia tenera (syn. $V$. tenera), Latin American mock vervain.
G. tenuisecta is from open sunny habitats in South America and has become naturalized in the western and southern United States, whereas Glandularia tenera is from similar habitats in Brazil. Considering the native habitats, Glandularia would be assumed to be more drought resistant. Another characteristic of Glandularia that might have contributed to its drought resistance is small, finely dissected blue-green foliage (Daubenmire, 1974; Larcher, 2003), which is known to reduce evapotranspiration. Other similar species of this genus are widely planted in low-water use landscapes across the southwestern U.S. (Lockett et al., 2002).

Although Petunia quality was reduced to the greatest degree from $25 \%$ to $0 \% \mathrm{ET}_{0}$, as indicated by the quadratic trend (Table 2), it was still aesthetically acceptable. Petunia has many characteristics that make it an ideal candidate for a low-water use landscape, primarily its ability to tolerate a broad range of temperatures. van Iersel (2003) reported that Petunia had the greatest daily carbon gain in response to short-term high temperatures when compared with geraniums and pansies. Both Glandularia and Petunia maintained a satisfactory plant quality of three points or more in spite of elevated canopy temperatures of more than $5{ }^{\circ} \mathrm{C}$ greater than the air temperature (Table 3 ).

Glandularia and Petunia grew well at all the irrigation levels, increasing in percent cover, change in percent cover, and plant biomass (Tables 4-6). Considering 75\% coverage to be ideal, Glandularia performed best at $25 \%$ and greater $\mathrm{ET}_{0}$, and Petunia at $75 \%$ and greater $\mathrm{ET}_{0}$.

The genera Catharanthus, Rudbeckia, Salvia, Senecio, Tagetes, and Zinnia all had a rating of three points or more at $25 \%$ and greater $\mathrm{ET}_{0}$ (Table 2). All these genera are

Table 3. Canopy-air temperature difference $\left(\Delta \mathrm{T}^{\circ} \mathrm{C}\right)$ for 17 bedding plant species and Kentucky bluegrass grown at five irrigation levels based on evapotranspiration for Kentucky bluegrass $\left(\mathrm{ET}_{0}\right)$ in Denver, Fort Collins, and Grand Junction, Colo.

\begin{tabular}{|c|c|c|c|c|c|c|c|c|c|c|}
\hline \multirow[b]{3}{*}{ Species } & \multicolumn{5}{|c|}{ Irrigation level $\left(\% \mathrm{ET}_{0}\right)$} & & & & & \\
\hline & 100 & 75 & 50 & 25 & 0 & \multicolumn{5}{|c|}{ ANOVA } \\
\hline & \multicolumn{5}{|c|}{$\left(\Delta \mathrm{T}^{\circ} \mathrm{C}\right)$} & Irrigation & Location & $\mathrm{I} \times \mathrm{L}$ & Linear & Quadratic \\
\hline Antirrhinum & -0.57 & 0.44 & 1.80 & 4.10 & 5.45 & 0.0006 & 0.0001 & 0.0064 & 0.0001 & NS \\
\hline Begonia & 4.23 & 5.15 & 6.68 & 10.18 & 12.49 & 0.0045 & 0.0001 & 0.0001 & 0.0004 & NS \\
\hline Catharanthus & 0.07 & 1.06 & 2.34 & 4.90 & 6.13 & 0.0008 & 0.0001 & 0.0046 & 0.0001 & NS \\
\hline Dianthus & 1.26 & 2.34 & 3.64 & 6.17 & 7.56 & 0.0007 & 0.0001 & 0.0006 & 0.0001 & NS \\
\hline Impatiens & 1.28 & 2.27 & 4.87 & 7.81 & 10.1 & 0.0082 & 0.0001 & 0.0028 & 0.0006 & NS \\
\hline Lobelia & 1.44 & 2.12 & 4.01 & 5.55 & 7.06 & 0.0020 & 0.0001 & 0.0021 & 0.0001 & NS \\
\hline Lobularia & -0.76 & -0.38 & 0.61 & 3.01 & 7.08 & 0.0017 & 0.0001 & 0.0138 & 0.0002 & 0.0260 \\
\hline Pelargonium & -0.30 & 1.78 & 3.77 & 6.77 & 9.67 & 0.0001 & 0.0001 & NS & 0.0001 & NS \\
\hline Petunia & -1.38 & -0.77 & 1.12 & 3.10 & 5.26 & 0.0036 & 0.0001 & 0.0005 & 0.0003 & NS \\
\hline Poa & 1.37 & 2.59 & 5.57 & 9.99 & 16.7 & 0.0009 & 0.0001 & 0.0001 & 0.0001 & NS \\
\hline Rudbeckia & -1.26 & 0.013 & 0.097 & 2.62 & 5.17 & 0.0009 & 0.0001 & 0.0347 & 0.0001 & NS \\
\hline Salvia & -1.52 & -0.53 & 1.39 & 3.11 & 5.06 & 0.0007 & 0.0001 & 0.0054 & 0.0001 & NS \\
\hline Senecio & -2.01 & -0.96 & 0.18 & 2.23 & 3.08 & 0.0008 & 0.0001 & 0.0294 & 0.0001 & NS \\
\hline Tagetes erecta & -2.54 & -1.33 & 0.065 & 2.51 & 3.99 & 0.0008 & 0.0001 & 0.0016 & 0.0001 & NS \\
\hline T. patula & -1.27 & -0.40 & 0.95 & 2.75 & 4.76 & 0.0258 & 0.0001 & 0.0001 & 0.0022 & NS \\
\hline Glandularia & -0.94 & -0.16 & 1.46 & 4.02 & 5.95 & 0.0009 & 0.0001 & 0.0001 & 0.0001 & NS \\
\hline Viola & 1.45 & 2.75 & 4.99 & 7.42 & 9.75 & 0.0016 & 0.0001 & 0.0005 & 0.0001 & NS \\
\hline Zinnia & -2.67 & -0.83 & 1.01 & 2.01 & 4.18 & 0.0008 & 0.0001 & 0.0090 & 0.0001 & NS \\
\hline
\end{tabular}

${ }^{\mathrm{Ns} N o n s i g n i f i c a n t .}$

Table 4. Percent cover of 17 bedding plant species grown at five irrigation levels based on evapotranspiration for Kentucky bluegrass (ET $)_{0}$ in Denver, Fort Collins, and Grand Junction, Colo.

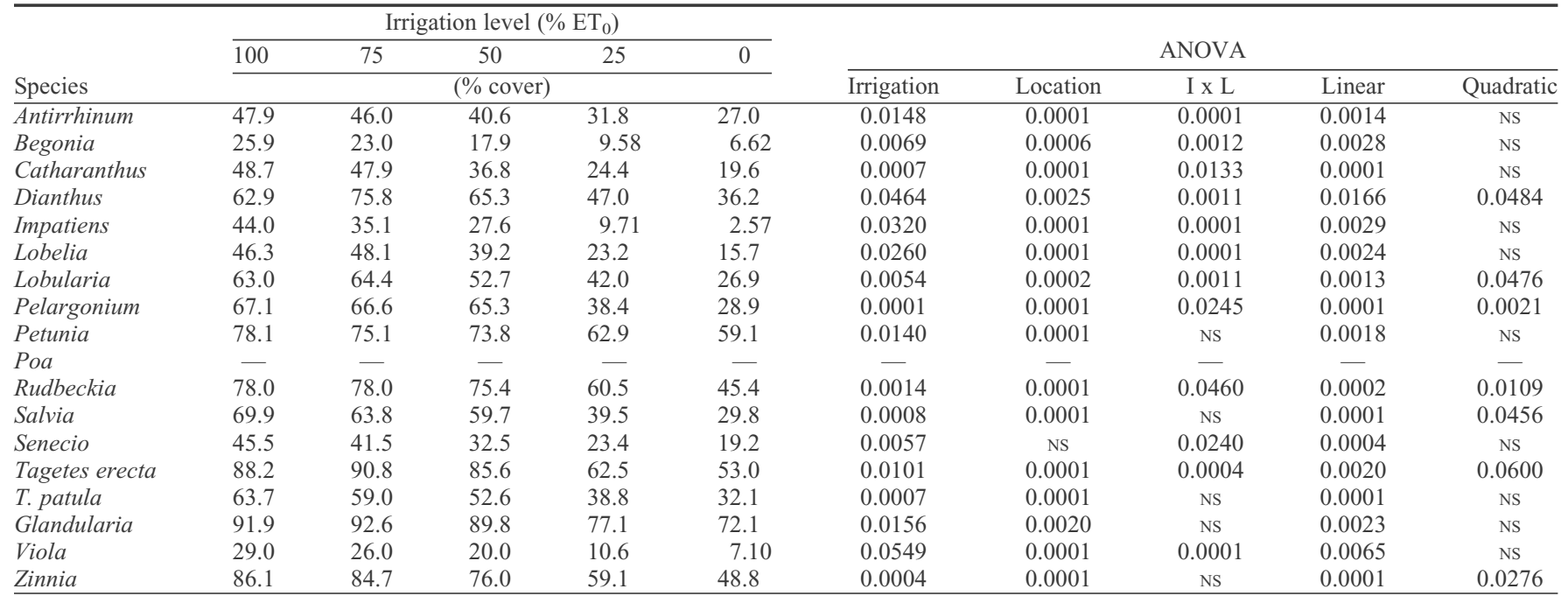

${ }^{\mathrm{N}}$ Nonsignificant. 
Table 5. Change in percent cover of 17 bedding plant species grown at five irrigation levels based on evapotranspiration for Kentucky bluegrass $\left(\mathrm{ET}_{0}\right)$ in Denver, Fort Collins, and Grand Junction, Colo.

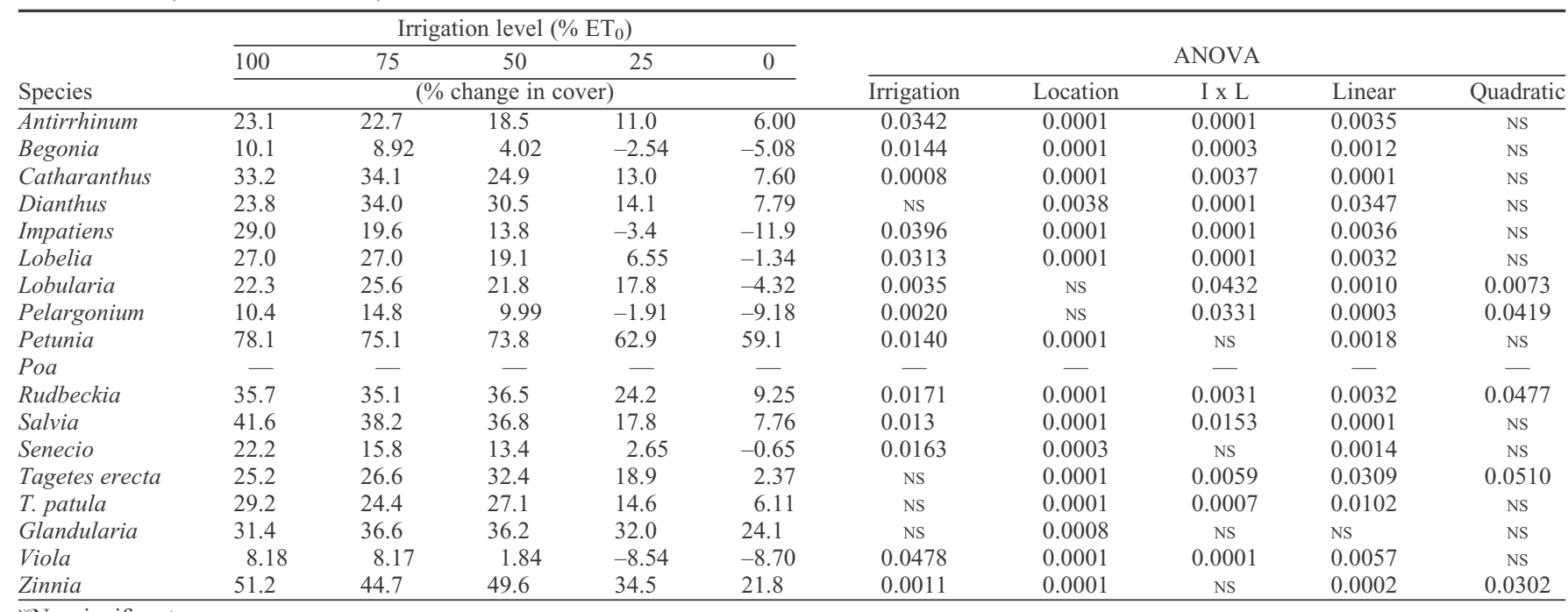

Nonsignificant.

Table 6. Plant biomass (in grams) of 17 bedding plant species grown at five irrigation levels based on evapotranspiration for Kentucky bluegrass $\left(\mathrm{ET}_{0}\right)$ in Denver and Fort Collins, Colo.

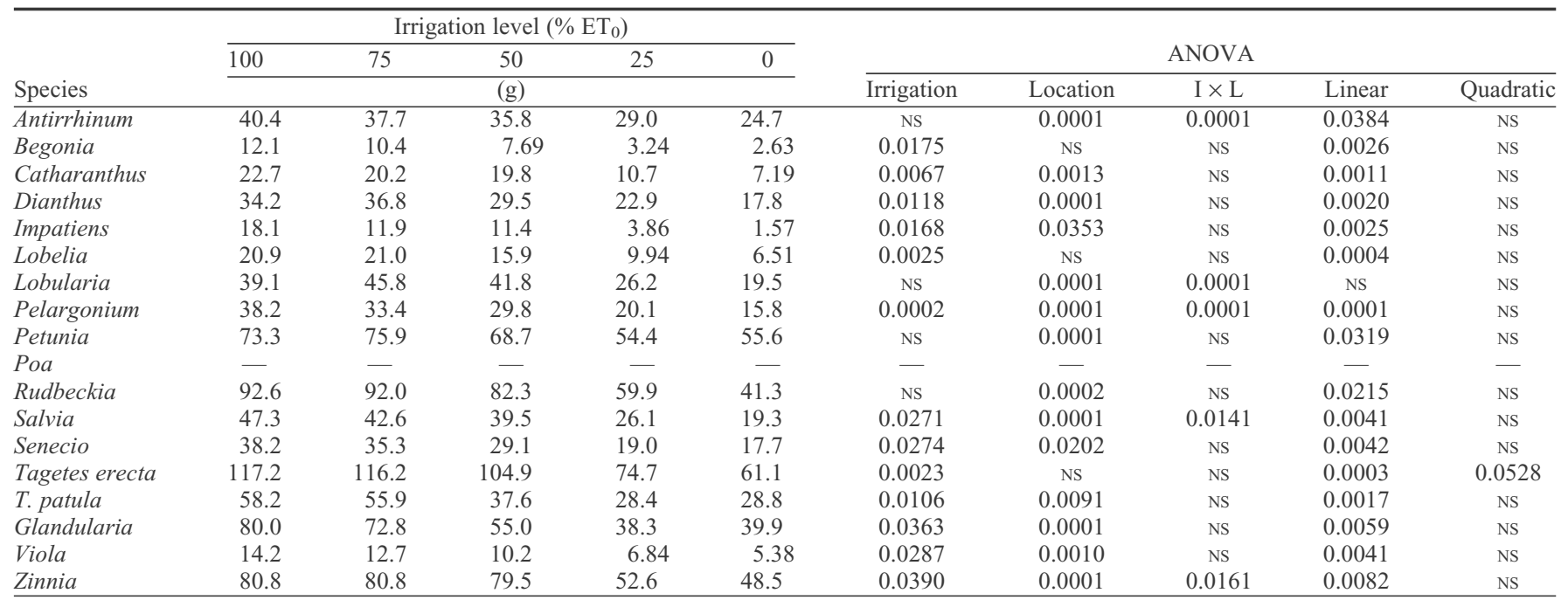

${ }^{\text {Ns Nonsignificant. }}$

native to hot and dry climates, thus it would be expected that they perform well in our study. Of these, Rudbeckia, T. erecta, and Zinnia achieved a coverage of $75 \%$ or more at $50 \% \mathrm{ET}_{0}$ (Table 4) while increasing in canopy size (Tables 5 and 6).

Antirrhinum, Dianthus, and Lobularia required at least $50 \% \mathrm{ET}_{0}$ and Begonia, Lobelia, Pelargonium, and Viola required at least $75 \% \mathrm{ET}_{0}$ to achieve a quality rating of three points or more (Table 2). None of these genera achieved $75 \%$ coverage (Table 4) nor did they grow well at irrigation levels lower than 50\% $\mathrm{ET}_{0}$ (Tables 4-6). These genera were also under considerable drought stress at irrigation levels less than $50 \% \mathrm{ET}_{0}$, as shown by high $\Delta \mathrm{T}$ values (Table 3 ). Many of these species are better adapted to cooler climates.

Antirrhinum grow best at cooler temperatures and, with recurrent wilting, flower quality declines (Rutland et al., 1987).
Wax-leaved begonias are considered to be drought resistant (Armitage, 2001), but under our conditions of high light, this trait was not observed. The Kentucky bluegrass included in the study required at least $50 \% \mathrm{ET}_{0}$ to maintain acceptable quality (Table 2).

Impatiens performed the poorest of all genera tested. It received a three points or more rating only when irrigated at $100 \% \mathrm{ET}_{0}$ (Table 2), but never achieved acceptable growth under our ambient conditions (Tables 4-6). This was anticipated, because this genus is typically planted in moderate to full shade in Colorado. Including Impatiens in this study was debated, yet these data support its potential success in the landscape when adequate irrigation is provided.

Many species adapted to lower irrigation rates had leaf temperatures near $0{ }^{\circ} \mathrm{C}$ or less at $100 \% \mathrm{ET}_{0}$ (Table 3). Typically leaf temperature increases as water stress increases (Hatfield, 1990; Smiciklas et al., 1989). Rose and colleagues (1994) determined that, for greenhouse roses, the leaf-air temperature difference was inversely related to transpiration rate. At any point where $\Delta \mathrm{T}$ is near $0{ }^{\circ} \mathrm{C}$ or less, plants are transpiring efficiently. Yet some species may maintain lower leaf temperatures through leaf color or adaptive leaf morphology by effectively reflecting solar radiation (Larcher, 2003). Lobularia, Petunia, Rudbeckia, Saliva, Tagetes, Glandularia, and Zinnia all had $\Delta \mathrm{T}$ values near $0{ }^{\circ} \mathrm{C}$ or less even at $75 \% \mathrm{ET}_{0}$ (Table 3 ).

The majority of the species evaluated in this study grew well with a minimum of $50 \%$ or more $\mathrm{ET}_{0}$ based on Kentucky bluegrass. Species considered to be heat or drought tolerant, Petunia and Glandularia, required little or no irrigation. The species included in this study, which are adapted to midsummer heat and low water, performed well with $25 \%$ or more $\mathrm{ET}_{0}$, indicating that these species can adapt to low-water landscape installations. 
This information will be beneficial for water providers to make recommendations about plant selection, planting design, and irrigation for plants in the Rocky Mountain west.

\section{Literature Cited}

Al-Kaisi, M.M. and I. Broner. 2002. Crop water use and growth stages. Colorado State Univ. Cooperative Extension. Fact sheet 4.715

Armitage, A.M. 2001. Manual of annuals, biennials, and half-hardy perennials. Timber Press, Portland, Ore.

Cox, R.A. and J.E. Klett. 1984. Evaluation of some indigenous western plants for xeric landscapes. HortScience 19:856-858.

Daubenmire, R. 1959. A canopy-coverage method of vegetative analysis. Northwest Sci. 33:1959.

Daubenmire, R.F. 1974. Plants and environment: A textbook of autecology (3rd ed.). Wiley, New York.

Doesken, N. 2004. Colorado Climate Center website. Learn About the climate of colorado. 14 Apr. 2004. http://ccc.atmos.colostate.edu/ climateofcolorado.php.

Ellefson, C. and D. Winger. 2004. Xeriscape Colorado: The complete guide. Westcliffe Publishers, Englewood, Colo.
Hatfield, J.L. 1990. Measuring plant stress with an infrared thermometer. HortScience 25:15351538 .

Larcher, W. 2003. Physiological plant ecology: Ecophysiology and stress physiology of functional groups. 4th ed. Springer-Verlag, Berlin.

Lockett, L., G. Montague, C. McKenney, and D. Auld. 2002. Assessing public opinion on water conservation and water conserving landscapes in the semiarid southwestern United States. HortTechnology 12:392-396.

Oad, R.T and M. DiSpigno. 1997. Water rights to return flow from urban landscape irrigation. J Irrig. Drainage Eng. July/Aug.:293-300.

Oad, R., K. Lusk, and T. Podmore. 1997. Consumptive use and return flows in urban water use. J Irrig. Drainage Eng. Jan./Feb.:62-69.

Pittenger, D.R., D.R. Hodel, and D.A. Shaw. 1990 Relative water requirements of six groundcover species. HortScience 25:1085. (abstr.).

Pittenger, D.R., D.R. Hodel, D.A. Shaw, and D.B. Holt. 1992. Minimum irrigation of landscape groundcovers. HortScience 27:5710. (abstr.)

Qian, Y.L., J.D. Fry, S.C. Wiest, and W.S. Upham. 1996. Estimating turfgrass evapotranspiration using atmometers and the Penman-Monteith model. Crop Sci. 36:699-704.
Rose, M.A., D.J. Beattie, and J.W. White. 1994 Oscillations of whole-plant transpiration in 'Moonlight' rose. J. Amer. Soc. Hort. Sci. 119:439-445.

Rutland, R.B., H.L.L. Chang, and J.E. Pallas, Jr. 1987. Stomatal density of snapdragon as a possible determinant of transpiration. HortScience 22:599-601.

Sachs, R.M. 1991. Stress-adapted landscapes save water, escape injury in drought. Calif. Agr. 45:19-21.

Smiciklas, K.D., R.E. Mullen, R.E. Carlson, and A.D. Knapp. 1989. Drought-induced stress effect on soybean seed calcium and quality Crop Sci. 29:1519-1523.

Staats, D. and J. Klett. 1995. Water conservation potential and quality of non-turf groundcovers versus Kentucky bluegrass under increasing levels of drought stress. J Env. Hort. 13:181185

Tweit, S.J. 2004. Rocky Mountain garden survival guide. Fulcrum Publishing, Golden, Colo.

van Iersel, M. 2003. Short-term temperature change affects carbon exchange characteristics and growth of four bedding plan species. J. Amer. Soc. Hort. Sci. 128:100106 